OPEN ACCESS

Edited by:

Ulrich Sack

Leipzig University, Germany

Reviewed by:

Olaf Stuve,

University of Texas Southwestern

Medical Center, United States

Eugenio Pucci,

ASUR Marche, Italy

*Correspondence:

Brigitte Le Mauff

lemauff-b@chu-caen.fr

Specialty section:

This article was submitted to Cancer Immunity and Immunotherapy,

a section of the journal

Frontiers in Immunology

Received: 07 April 2020 Accepted: 04 September 2020

Published: 24 September 2020

Citation:

Khoy K, Mariotte D, Defer G,

Petit G, Toutirais $O$ and Le Mauff $B$

(2020) Natalizumab in Multiple

Sclerosis Treatment: From Biological

Effects to Immune Monitoring.

Front. Immunol. 11:549842.

doi: 10.3389/fimmu.2020.549842

\section{Natalizumab in Multiple Sclerosis Treatment: From Biological Effects to Immune Monitoring}

\author{
Kathy Khoy ${ }^{1}$, Delphine Mariotte ${ }^{1}$, Gilles Defer ${ }^{2,3,4}$, Gautier Petit ${ }^{1}$, Olivier Toutirais ${ }^{1,3,4}$ and \\ Brigitte Le Mauff $1,3,4 *$
}

${ }^{1}$ Laboratory of Immunology, Department of Biology, CHU Caen Normandie, Caen, France, ${ }^{2}$ Department of Neurology, MS Expert Centre, CHU Caen Normandie, Caen, France, ${ }^{3}$ UMR-S1237, Physiopathology and Imaging of Neurological

Disorders, INSERM, Caen, France, ${ }^{4}$ Normandie Université, UNICAEN, Caen, France

Multiple sclerosis is a chronic demyelinating disease of the central nervous system (CNS) with an autoimmune component. Among the recent disease-modifying treatments available, Natalizumab, a monoclonal antibody directed against the alpha chain of the VLA-4 integrin (CD49d), is a potent inhibitor of cell migration toward the tissues including CNS. It potently reduces relapses and active brain lesions in the relapsing remitting form of the disease. However, it has also been associated with a severe infectious complication, the progressive multifocal leukoencephalitis (PML). Using the standard protocol with an injection every 4 weeks it has been shown by a close monitoring of the drug that trough levels soon reach a plateau with an almost saturation of the target cell receptor as well as a down modulation of this receptor. In this review, mechanisms of action involved in therapeutic efficacy as well as in PML risk will be discussed. Furthermore the interest of a biological monitoring that may be helpful to rapidly adapt treatment is presented. Indeed, development of anti-NAT antibodies, although sometimes unapparent, can be detected indirectly by normalization of CD49d expression on circulating mononuclear cells and might require to switch to another drug. On the other hand a stable modulation of CD49d expression might be useful to follow the circulating NAT levels and apply an extended interval dose scheme that could contribute to limiting the risk of PML.

Keywords: multiple sclerosis, natalizumab, biotherapy, drug modifying therapy, Mab therapy monitoring, Integrin, neutralizing antibodies, PML

\section{INTRODUCTION}

Multiple sclerosis (MS) is a chronic, inflammatory autoimmune disease leading to demyelination. It is a heterogeneous, multifactor disease with environment factors acting in a susceptibility genetic background, still only partially described. Following a silent phase, the most common clinical form of MS is the relapsing remitting MS (RRMS) with accumulation of lesions during relapse phases. With time the disease may evolve as a progressive phase without remission (secondary progressive MS, SPMS) although some patients may have a progressive disease from the onset called primary progressive MS (1). Although few treatments are active on the progressive forms of MS, the treatment of RRMS has been dramatically modified in the era of monoclonal antibodies and other disease modifying therapies (DMT). 
Among them, Natalizumab (Tysabri ${ }^{\circledR}$, NAT) is a humanized IgG4 antibody (Ab) that recognizes $\alpha 4$ chain $(\mathrm{CD} 49 \mathrm{~d})$ of the VLA4 (Very Late Antigen 4) antigen, a component of the $\alpha 4 \beta 1$ integrin, and of the $\alpha 4 \beta 7$ integrin. It is the clinical achievement of the pioneer work of Yednok et al., who demonstrated the role of this adhesion molecule in the interaction of leukocytes with inflamed endothelium in the brain and had shown that the injection of an anti- $\alpha 4$ monoclonal antibody prevents EAE (experimental autoimmune encephalomyelitis) in a rat MS model (2). Consequently, a mouse anti-human $\alpha 4$ chain $\mathrm{Ab}$ able to block VLA4 interaction with its ligand VCAM1 (Vascular Cellular Adhesion Molecule1) was selected for humanization (3). Two phase III studies demonstrated the efficacy of NAT to improve the evolution of RRMS in terms of annual relapses or development of brain MRI lesions $(4,5)$. This success was not obtained in SPMS (6). In addition, a severe adverse effect was then reported with the appearance of progressive multifocal encephalopathy (PML) (7) which was usually occurring in immuno-compromised or immunosuppressed patients. The standardized protocol consists in a $300 \mathrm{mg}$ dose every 4 weeks but many schemes extending interval dosing have been tested with similar efficacy (8-11).

\section{MECHANISMS OF ACTION}

The underlying MS pathological process involves both antigen specific and non specific inflammatory mechanisms. Part of the knowledge is coming from animal studies using the EAE model (12) but contradictory features concerning the human pathology have emerged from several therapeutic trials. For example, the central role of antigen specific T cells observed in EAE has been extended from CD4+ T cells in EAE to more numerous CD8+ $\mathrm{T}$ cells in human with autoreactivity against myelin derived peptides, and from a critical role of Th1 cells secreting IFN $\gamma$ to the participation of Th17 cells producing GM-CSF $(13,14)$. The importance of B cells has long been recognized with the presence of oligoclonal bands in CSF, but the recent evidence of the efficacy of therapies depleting these cells without significant effects on immunoglobulins shifts their role toward their ability to present antigens to $\mathrm{T}$ cells (15). Furthermore a complex inflammatory infiltrate in central nervous system (CNS) and CSF is described including various innate cells that complete the role of the locally activated microglia. Whatever the mechanisms, the activation of antigen specific lymphocytes either in the periphery or not, and the secondary colonization of CNS need cell interactions and migration which are dependent on chemokines and adhesion molecules. The rationale for using anti- $\alpha 4$ Abs in EAE was their blocking effect on the adhesion of leukocytes leading to inhibition of inflammatory migration to CNS. Although a large body of results strengthen this strategy, some pre-clinical data suggest that according to the timing of monoclonal $\mathrm{Ab}$ (Mab) administration or the experimental model, anti- $\alpha 4$ Abs can be inefficient or deleterious despite VLA4 blockade $(16,17)$, possibly because of agonistic properties of anti-VLA4 Abs (17). Nevertheless the activating effect of anti-VLA4 Abs has not been described in NAT treated patients (18-20). In addition, in
EAE models, infiltration of Th17 cells or GM-CSF-producing Th1/Th17 cells into the CNS has been shown to be mediated by lymphocyte function associated antigen 1 (LFA1) adhesion molecules and not VLA4 integrin, thereby suggesting more differential effects of anti-VLA4 blockade, at least, in animal models $(21,22)$.

By preventing the interaction of $\alpha 4 \beta 1$ integrin expressed on lymphocytes to its ligand VCAM1 on endothelial cells, NAT inhibits the migration through the brain blood barrier into the CNS parenchyma. There are two ways to confirm this effect: in the blood compartment, an increase of leukocytes has already been observed (23) whereas a decrease of infiltrating cells could be assessed in the CSF. Evidently, CNS infiltrating lymphocytes were decreased in patients treated with NAT as compared to untreated patients or pre-treatment levels. This was observed for T lymphocytes, mainly for CD4+ cells, and for B cells (24-28) and led to a diminished level of immunoglobulins (IgM, IgG) including oligoclonal bands, with a decrease of local production $(24,27-29)$. These effects were confirmed in longitudinal studies and disappeared - albeit slowly (within 6 months) - after treatment interruption (26). Monocytes were increased relatively to lymphocytes during treatment suggesting that their migration might be less VLA4-dependent $(30,31)$. Few reports analyzed the effects of NAT on antigen presenting cells, but a reduced number of dendritic cells (DCs) had been observed in perivascular spaces in post mortem samples of a NAT treated patient (32). Furthermore, in addition to a decreased expression of CD49d, both myeloid and plasmacytoid DCs had impaired capacities to stimulate T lymphocytes (33).

As a consequence of this extravasation blockade, mononuclear cells accumulate in the circulation. In addition, some haematopoietic precursors might be released from the bone marrow due to loss of VLA4-VCAM1 interactions with the stromal cells or altered homing $(34,35)$. The net result is an important lymphocytosis following the first injection which soon reached a stable plateau. The more altered cells were B lymphocytes (more than 3 times pre-treatment values), NK and $\mathrm{T}$ lymphocytes (2 and 1.8, respectively) without modification of the CD4+/CD8+ ratio (36-38). Cell numbers decreased after 8 weeks of treatment interruption and returned to basal levels around 16 weeks after this interruption (38). The phenotype and function of the circulating cells have been explored and inconstantly showed an increase of memory $\mathrm{T}$ cells which might reflect their higher CD49d expression, and of activated cells $(18,39,40)$. Although Th17 or Th1/17 cell migration has been suggested to be partially VLA-4 dependent (31), it is mostly observed that under NAT treatment these cells also accumulate in the circulation $(41,42)$. Furthermore, the frequencies or proliferative capacities of potential encephalogenic myelin basic protein reactive cells were not modified under NAT treatment (39). Some variations in cytokine production merely proinflammatory were also observed, especially in the early phases of treatment $(39,43,44)$. In contrast, no quantitative nor qualitative effect was noted on regulatory $\mathrm{T}$ cells (Tregs) $(18,45)$. These cells constantly showed a strong decrease of CD49d expression $(46,47)$ but their migration was still efficiently blocked and their suppressive effects preserved (47). B cells were the most impacted 
circulating cells and also demonstrated a memory phenotype, prone to activation, and pro-inflammatory profile $(25,40,48)$.

A direct activation role of natalizumab through CD49d has been excluded for all types of cells $(25,39)$ arguing for a mere accumulation in the circulation of cells potentially activated, due to the inhibition of migration. It might favor the recurrence of the disease after treatment interruption, observed in approximately one third of the cases, which needs a switch to another treatment (49). In some cases a more severe relapse is observed as compared to the pre-treatment status of the patient, described as a rebound effect (50) and can be related to the migration of autoreactive Th1, Th17, or Th1/17 cells accumulated in the circulation during NAT treatment $(41,42)$.

\section{PML COMPLICATION}

Progressive multifocal encephalopathy, a demyelinating disease caused by the John Cunningham virus (JCV), was soon observed in NAT treated patients although it was previously associated with immunodeficiency or immunosuppression (7). Despite a high incidence (1/1000) with an 18-month treatment, (51), a clear benefit/risk balance reinstated it after a short market withdrawal. In MS treatment, other drugs such as anti-B cell Mabs (anti-CD20 Mabs), dimethyl fumarate, or fingolimod had an increase of PML risk, but far less than NAT (52). Another anti-adhesion molecule, efalizumab (anti-LFA-1) used in psoriasis, has been withdrawn because of PML complications (53). The concept of altered immune surveillance to virus in CNS due to the cell circulation migration inhibition has long been the main argument described as the cause of this increased risk. However, some properties of NAT might facilitate this disease. The JCV infection is a very frequent asymptomatic disease usually occurring during childhood, then remaining latent until a possible reactivation, which remains a very rare event. Although the knowledge of JCV biology has greatly improved, some critical issues persist about the process of latency and reactivation (54). It has been suggested that the increase of circulating haematopoietic precursors and/or the accumulation of pre-B and B cells $(34,35,55-58)$ might represent a potential virus reservoir for $\operatorname{JCV}(59,60)$. Analysis of JCV in these cells showed some conflicting results $(35,60-63)$, probably depending on method sensitivity. Nevertheless, when detectable, it should be mentioned that the virus is detected at low levels or under inactive form; and sometimes in asymptomatic patients $(60,61,64)$. These data are consistent with a latency phase of the virus. In addition, normal brain might also be another site of latent viral persistence (65).

It has been shown that NAT is able to upregulate transcription regulators POU2AF1 and Spi-B in B cells $(59,66)$. Consequently, transition from latent archetype to prototype virus variant, viral transcription and replication are suspected to be facilitated in lymphoid cells $(60,62,67)$. Spreading to CNS through B cells or free virions is speculated but has not been proven (68). But, even if this hypothesis is true in immunocompetent people, it is likely that the spreading would be inhibited under NAT treatment. On the target cell side, NAT has not been shown to facilitate neural cell infection, at least in vitro (69). In the context of immune modulation induced by NAT, there is a decrease in antigen presenting cells in the CNS (32), and the trafficking of memory $\mathrm{T}$ cells is not selectively inhibited by NAT. It has also been shown that the anti-viral Th1 compartment is retained in the circulation hampering the JCV elimination (41). At this stage, the main parameters for susceptibility to JCV infection are NAT treatment longer than 2 years, prior immunosuppression and anti-JCV seropositivity.

\section{DRUG MONITORING}

\section{Circulating and CSF Levels of NAT}

As for most drugs, the measurement of concentrations is a tool to determine the best dosage. Various methods have been used to measure NAT concentrations. Due to its heterodimeric structure, cellular assays have been developed using cells expressing CD49d and FACS analysis with a standard curve of NAT (70, 71). Alternatively ELISA methods have been set up. A particular property of the IgG4 isotype that has been uncovered is that due to the absence of covalent links between the two heavy chains, "Fab arm exchange" occurs between IgG4, rendering them monovalent (72). In addition to potentially modifying NAT functional effect, it can directly interfere with detection assays. Accordingly, an alternative to classical bridging test has been developed (73) but no strict comparison measurements have been thoroughly published yet. The variable median results of NAT free circulating levels observed among studies (from 18 to $51 \mu \mathrm{g} / \mathrm{ml}$ ) may be assay dependent, but a common characteristics noted within each study was the high variability among patients (less than $4 \mu \mathrm{g}$ and up to 100 or $200 \mu \mathrm{g})(71,74,75)$. No clear relationship has been evidenced to identify factors involved in this heterogeneity although body weight might contribute (76, 77). Nevertheless, for a given patient, trough levels soon reach a plateau and remain stable whatever the number of infusions (9) and for more than $90 \%$ of them were over $10 \mu \mathrm{g} / \mathrm{ml}$ (78). In comparison, levels within CSF were a hundred times lower from 45 to $110 \mathrm{ng} / \mathrm{ml}(71,74)$.

In the serum, free NAT was measured, but the cell bound part can also be determined. Cytometry allows determining the level of NAT bound to cells using a fluorescent anti-IgG4 antibody, as well as the free CD49d molecules on the cells that are not covered by the administered drug, using an additional incubation with an excess of NAT. This assay is suitable for determining the saturation level of CD49d on the cells which, although slightly different according to the circulating cell type analyzed, is around $70 \%$ (79, 80). Surprisingly, and despite the low levels of free NAT measured in CSF, nearly the same degree of saturation was observed in CSF (79).

These assays were performed during ongoing treatment but the disappearance of NAT was also evaluated in studies performed after interruption of treatment $(38,81)$. In the RESTORE study designed to evaluate the consequences of treatment interruption, NAT circulating levels after the last injection differed from patients still treated 8 weeks after interruption of treatment, and it takes 16 weeks for the NAT levels to become undetectable (38). In parallel, at the same time, the 
saturation of circulating cells started to decrease ( $68 \%$ vs $87 \%$ for treated patients) but some antibody remains detectable on the cells between 16 and 28 weeks after interruption (38).

When the clearance of NAT needs to be very rapid, for instance because of PML, protocols of plasma exchange are used and allows almost $90 \%$ elimination of circulating NAT within 1 week. In these conditions, the saturation of the cells falls under $50 \%$ when NAT is $<1 \mu \mathrm{g} / \mathrm{ml}$, and partial restoration of migratory capacities is obtained 3 weeks after plasma exchange treatment (82). It should be mentioned that this strategy is not without risk. In addition to a potential reactivation of the disease, it may represent a worsening factor in PML, inducing an immune reconstitution inflammatory syndrome (IRIS) that leads to a poorer prognosis that in case of spontaneous NAT clearance (83).

\section{Pharmacodynamic Analysis}

These pharmacokinetics parameters have been completed by pharmacodynamic analysis checking some dose-dependent functional effect. Parallel to the receptor saturation, it could be noticed that CD49d expression, as determined using a fluorescent anti-CD49d antibody recognizing another epitope, was decreased around $50 \%$ of the pre-treatment level soon after treatment initiation $(19,70,71,84)$. It then remained stable all along treatment except in cases of immunization (cf infra). This diminished expression, associated with a decrease of CD29, the $\beta 1$ chain of this heterodimer, (84) might contribute to the inhibition of VLA4/VCAM interactions. The recovery of the expression after treatment interruption is slower than the decrease of receptor occupancy (9).

Using fluorescent beads allowing quantification (Quantibrite, $\mathrm{BD})$, a more precise evaluation has been performed to compare the number of membrane expressed CD49d molecules and the number of bound NAT molecules (85). It allows a direct estimation of the level of saturation in patients receiving standard protocol (Standard interval dosing SID, 4 weeks) or protocols with an extended interval (EID) between two injections. This schedule was evaluated in order to limit the risk of PML. Using a regular treatment, T CD4, CD8, B cells expressed, according to the cell type, around 1300-1400 CD49d molecules. In contrast with an interval of 6 weeks between injections, the number of CD49d was 2000-2400 molecules/cell. Nevertheless, the number of NAT bound molecules was not different between the 2 groups leading to decreased receptor occupancy (RO) from $76-84 \%$ to $54-62 \%$ (85). Using a simple measurement of the mean fluorescence intensity of an antiCD49d antibody, a modest increase of CD49d expression was observed in EID (9\%) as compared to SID, still at $60 \%$ of the pre-treatment levels, and it was associated with a decrease of NAT circulating levels from 36 to $18 \mu \mathrm{g} / \mathrm{ml}$ (9). These trough levels are still over the levels needed for an almost receptor saturation. With these EID protocols, no worsening of the clinical status was noticed suggesting that increasing the time between injections is not altering efficacy $(10,11)$.

So, biological parameters for monitoring the interval injection duration are available. As far as now, no studies have determined a critical level for saturation or modulation of CD49d required for clinical efficacy. These parameters might be useful for an adaptation of dose or timing on a case by case basis to limit the adverse biological effects of NAT.

\section{Anti-drug Antibodies}

Therapeutic strategies were greatly completed by introducing monoclonal antibodies but despite the molecular engineering of humanized molecules these proteins keep a potential immunogenicity especially when used as monotherapy. In the case of NAT, nearly $9 \%$ of the patients were identified with anti-NAT antibodies, and 6\% are immunized permanently (4). For some patients the injection related side effects suggest immunization, that needs to be investigated, whereas for many of them the process is silent or relapses might occur by therapy inhibition. For these patients, a systematic screening for immunization has been suggested at 6 months. The presence of high titers of anti-NAT antibodies is suggestive of a permanent immunization. Depending on the test used, no clear cut-off has yet been defined $(75,86,87)$. However, in our experience, transient anti-NAT Ab were detected at rather low levels (10 times less) as compared to patients with persistent neutralizing antibodies (70). The neutralizing effect of immunization can also be suggested by using the monitoring parameters previously discussed. Among them, the end of CD49d expression downmodulation is suggestive of the immunization (70) which can be either transient or permanent.

Immunization is also responsible of NAT clearance, and complete disappearance of circulating free NAT was observed in immunized patients with clinical relapse (75). Depending on the local laboratory practice, it can be easier and more flexible to measure modulation of CD49d for a given patient than to perform complete series of natalizumab and anti-natalizumab ELISA. The measurement of the lymphocytosis has also been suggested to be a potential biomarker of efficacy (88) but has not been related to NAT levels, saturation, or anti-NAT antibody appearance.

In-depth analysis of the immune response of two patients has allowed the characterisation of the $\mathrm{B}$ and $\mathrm{T}$ cell responses. In contrast to the large polyclonal anti-idiotypic B response, an immunodominant $\mathrm{T}$ cell epitope was identified in the FR2CDR2 region of NAT light chain. In addition this epitope could be modified to avoid $\mathrm{T}$ cell recognition without loosing the binding to CD49d (89) providing a deimmunized antibody (90). Such a modified molecule could be an alternative for immunized patients.

In conclusion NAT is one of the recent therapies that have changed the evolution of RRMS. However, long term treatment has been associated with PML, a severe infectious complication. No specific biologic risk linked to NAT properties has been definitively identified in this susceptibility, which is also observed in other immunosuppression states either related to HIV or monoclonal antibody treatments or other DMT. In the context of NAT, no drug overdose was noticed at the time of infection (77) and risk evaluation remained to be assessed on treatment duration and anti JC antibody status. In order to limit the risk of PML, EID protocols seem to maintain a sufficient efficacy, although 
the real benefit on large cohorts has not yet been reported, and the ongoing NOVA study might contribute to this evaluation (91). On the other side, inefficient treatment might not always be clinically detectable until new release. In both circumstances, to offer an optimized treatment with potential therapeutic switch and to improve the cost/benefit, it might be interesting to develop an adapted biological monitoring using an easy-tomeasure parameter such as modulation of the expression of

\section{REFERENCES}

1. Baecher-Allan C, Kaskow BJ, Weiner HL. Multiple sclerosis: mechanisms and immunotherapy. Neuron. (2018) 97:742-68. doi: 10.1016/j.neuron.2018.01. 021

2. Yednock TA, Cannon C, Fritz LC, Sanchez-Madrid F, Steinman L, Karin N. Prevention of experimental autoimmune encephalomyelitis by antibodies against alpha 4 beta 1 integrin. Nature. (1992) 356:63-6. doi: 10.1038/ $356063 \mathrm{a} 0$

3. Leger OJ, Yednock TA, Tanner L, Horner HC, Hines DK, Keen S, et al. Humanization of a mouse antibody against human alpha-4 integrin: a potential therapeutic for the treatment of multiple sclerosis. Hum Antibodies. (1997) 8:3-16.

4. Polman CH, O'Connor PW, Havrdova E, Hutchinson M, Kappos L, Miller $\mathrm{DH}$, et al. A randomized, placebo-controlled trial of natalizumab for relapsing multiple sclerosis. N Engl J Med. (2006) 354:899-910. doi: 10.1056/ NEJMoa044397

5. Rudick RA, Stuart WH, Calabresi PA, Confavreux C, Galetta SL, Radue EW, et al. Natalizumab plus interferon beta-1a for relapsing multiple sclerosis. $N$ Engl J Med. (2006) 354:911-23. doi: 10.1056/NEJMoa044396

6. Kapoor R, Ho PR, Campbell N, Chang I, Deykin A, Forrestal F, et al. Effect of natalizumab on disease progression in secondary progressive multiple sclerosis. (ASCEND): a phase 3, randomised, double-blind, placebo-controlled trial with an open-label extension. Lancet Neurol. (2018) 17:405-15. doi: 10 1016/S1474-4422(18)30069-3

7. Berger JR, Koralnik IJ. Progressive multifocal leukoencephalopathy and natalizumab-unforeseen consequences. N Engl J Med. (2005) 353:414-6. doi: 10.1056/NEJMe058122

8. Bomprezzi R, Pawate S. Extended interval dosing of natalizumab: a two-center, 7-year experience. Ther Adv Neurol Disord. (2014) 7:227-31. doi: 10.1177/ 1756285614540224

9. Foley JF, Goelz S, Hoyt T, Christensen A, Metzger RR. Evaluation of natalizumab pharmacokinetics and pharmacodynamics with standard and extended interval dosing. Mult Scler Relat Disord. (2019) 31:65-71. doi: 10. 1016/j.msard.2019.03.017

10. Yamout BI, Sahraian MA, Ayoubi NE, Tamim H, Nicolas J, Khoury SJ, et al. Efficacy and safety of natalizumab extended interval dosing. Mult Scler Relat Disord. (2018) 24:113-6. doi: 10.1016/j.msard.2018.06.015

11. Zhovtis Ryerson L, Frohman TC, Foley J, Kister I, Weinstock-Guttman B, Tornatore C, et al. Extended interval dosing of natalizumab in multiple sclerosis. J Neurol Neurosurg Psychiatry. (2016) 87:885-9. doi: 10.1136/jnnp2015-312940

12. Constantinescu CS, Farooqi N, O’Brien K, Gran B. Experimental autoimmune encephalomyelitis. (EAE). as a model for multiple sclerosis. (MS). $\mathrm{Br} J$ Pharmacol. (2011) 164:1079-106. doi: 10.1111/j.1476-5381.2011.01302.x

13. Codarri L, Gyulveszi G, Tosevski V, Hesske L, Fontana A, Magnenat L, et al. RORgammat drives production of the cytokine GM-CSF in helper T cells, which is essential for the effector phase of autoimmune neuroinflammation. Nat Immunol. (2011) 12:560-7. doi: 10.1038/ni.2027

14. El-Behi M, Ciric B, Dai H, Yan Y, Cullimore M, Safavi F, et al. The encephalitogenicity of T(H)17 cells is dependent on IL-1- and IL-23-induced production of the cytokine GM-CSF. Nat Immunol. (2011) 12:568-75. doi: 10.1038/ni.2031

15. Hauser SL, Waubant E, Arnold DL, Vollmer T, Antel J, Fox RJ, et al. B-cell depletion with rituximab in relapsing-remitting multiple sclerosis. $\mathrm{N}$ Engl J Med. (2008) 358:676-88. doi: 10.1056/NEJMoa0706383
CD49d, which is a good and robust functional reflect of the circulating levels of NAT.

\section{AUTHOR CONTRIBUTIONS}

All authors contributed to manuscript revision, read and approved the submitted version.

16. Kerfoot SM, Norman MU, Lapointe BM, Bonder CS, Zbytnuik L, Kubes P. Reevaluation of P-selectin and alpha 4 integrin as targets for the treatment of experimental autoimmune encephalomyelitis. J Immunol. (2006) 176:622534. doi: 10.4049/jimmunol.176.10.6225

17. Theien BE, Vanderlugt CL, Eagar TN, Nickerson-Nutter C, Nazareno R, Kuchroo VK, et al. Discordant effects of anti-VLA-4 treatment before and after onset of relapsing experimental autoimmune encephalomyelitis. J Clin Invest. (2001) 107:995-1006. doi: 10.1172/JCI11717

18. Frisullo G, Iorio R, Plantone D, Marti A, Nociti V, Patanella AK, et al. CD4+Tbet+, CD4+pSTAT3+ and CD8+T-bet+ T cells accumulate in peripheral blood during NZB treatment. Mult Scler. (2011) 17:556-66. doi: 10.1177/ 1352458510392263

19. Niino M, Bodner C, Simard ML, Alatab S, Gano D, Kim HJ, et al. Natalizumab effects on immune cell responses in multiple sclerosis. Ann Neurol. (2006) 59:748-54. doi: 10.1002/ana.20859

20. Sato T, Tachibana K, Nojima Y, D'Avirro N, Morimoto C. Role of the VLA-4 molecule in $\mathrm{T}$ cell costimulation. Identification of the tyrosine phosphorylation pattern induced by the ligation of VLA-4. J Immunol. (1995) 155:2938-47.

21. Glatigny S, Duhen R, Oukka M, Bettelli E. Cutting edge: loss of alpha4 integrin expression differentially affects the homing of Th1 and Th17 cells. J Immunol. (2011) 187:6176-9. doi: 10.4049/jimmunol.1102515

22. Rothhammer V, Heink S, Petermann F, Srivastava R, Claussen MC, Hemmer B, et al. Th17 lymphocytes traffic to the central nervous system independently of alpha4 integrin expression during EAE. J Exp Med. (2011) 208:2465-76. doi: 10.1084/jem.20110434

23. Miller DH, Khan OA, Sheremata WA, Blumhardt LD, Rice GP, Libonati MA, et al. A controlled trial of natalizumab for relapsing multiple sclerosis. $N$ Engl J Med. (2003) 348:15-23. doi: 10.1056/NEJMoa020696

24. Mancuso R, Franciotta D, Rovaris M, Caputo D, Sala A, Hernis A, et al. Effects of natalizumab on oligoclonal bands in the cerebrospinal fluid of multiple sclerosis patients: a longitudinal study. Mult Scler. (2014) 20:1900-3. doi: $10.1177 / 1352458514538111$

25. Mellergard J, Edstrom M, Jenmalm MC, Dahle C, Vrethem M, Ernerudh J. Increased B cell and cytotoxic NK cell proportions and increased $\mathrm{T}$ cell responsiveness in blood of natalizumab-treated multiple sclerosis patients. PLoS One. (2013) 8:e81685. doi: 10.1371/journal.pone.008 1685

26. Stuve O, Marra CM, Bar-Or A, Niino M, Cravens PD, Cepok S, et al. Altered CD4+/CD8+ T-cell ratios in cerebrospinal fluid of natalizumabtreated patients with multiple sclerosis. Arch Neurol. (2006) 63:1383-7. doi: 10.1001/archneur.63.10.1383

27. Villar LM, Garcia-Sanchez MI, Costa-Frossard L, Espino M, Roldan E, Paramo $\mathrm{D}$, et al. Immunological markers of optimal response to natalizumab in multiple sclerosis. Arch Neurol. (2012) 69:191-7. doi: 10.1001/archneurol. 2011.971

28. Warnke C, Stettner M, Lehmensiek V, Dehmel T, Mausberg AK, von Geldern $\mathrm{G}$, et al. Natalizumab exerts a suppressive effect on surrogates of B cell function in blood and CSF. Mult Scler. (2015) 21:1036-44. doi: 10.1177/ 1352458514556296

29. Harrer A, Tumani H, Niendorf S, Lauda F, Geis C, Weishaupt A, et al. Cerebrospinal fluid parameters of B cell-related activity in patients with active disease during natalizumab therapy. Mult Scler. (2013) 19:1209-12. doi: 10. $1177 / 1352458512463483$

30. Dallari S, Franciotta D, Carluccio S, Signorini L, Gastaldi M, Colombo E, et al. Upregulation of integrin expression on monocytes in multiple sclerosis 
patients treated with natalizumab. J Neuroimmunol. (2015) 287:76-9. doi: 10.1016/j.jneuroim.2015.08.010

31. Schneider-Hohendorf T, Rossaint J, Mohan H, Boning D, Breuer J, Kuhlmann $\mathrm{T}$, et al. VLA-4 blockade promotes differential routes into human CNS involving PSGL-1 rolling of T cells and MCAM-adhesion of TH17 cells. J Exp Med. (2014) 211:1833-46. doi: 10.1084/jem.20140540

32. del Pilar Martin M, Cravens PD, Winger R, Frohman EM, Racke MK, Eagar $\mathrm{TN}$, et al. Decrease in the numbers of dendritic cells and CD4+ T cells in cerebral perivascular spaces due to natalizumab. Arch Neurol. (2008) 65:1596603. doi: 10.1001/archneur.65.12.noc80051

33. de Andres C, Teijeiro R, Alonso B, Sanchez-Madrid F, Martinez ML, Guzman de Villoria J, et al. Long-term decrease in VLA-4 expression and functional impairment of dendritic cells during natalizumab therapy in patients with multiple sclerosis. PLoS One. (2012) 7:e34103. doi: 10.1371/journal.pone. 0034103

34. Mattoscio M, Nicholas R, Sormani MP, Malik O, Lee JS, Waldman AD, et al. Hematopoietic mobilization: potential biomarker of response to natalizumab in multiple sclerosis. Neurology. (2015) 84:1473-82. doi: 10.1212/WNL. 0000000000001454

35. Saure C, Warnke C, Zohren F, Schroeder T, Bruns I, Cadeddu RP, et al. Natalizumab and impedance of the homing of CD34+ hematopoietic progenitors. Arch Neurol. (2011) 68:1428-31. doi: 10.1001/archneurol.2011. 238

36. Kaufmann M, Haase R, Proschmann U, Ziemssen T, Akgun K. Real-world lab data in natalizumab treated multiple sclerosis patients up to 6 years long-term follow up. Front Neurol. (2018) 9:1071. doi: 10.3389/fneur.2018.01071

37. Koudriavtseva T, Sbardella E, Trento E, Bordignon V, D'Agosto G, CordialiFei P. Long-term follow-up of peripheral lymphocyte subsets in a cohort of multiple sclerosis patients treated with natalizumab. Clin Exp Immunol. (2014) 176:320-6. doi: 10.1111/cei.12261

38. Plavina T, Muralidharan KK, Kuesters G, Mikol D, Evans K, Subramanyam $M$, et al. Reversibility of the effects of natalizumab on peripheral immune cell dynamics in MS patients. Neurology. (2017) 89:1584-93. doi: 10.1212/WNL. 0000000000004485

39. Bornsen L, Christensen JR, Ratzer R, Oturai AB, Sorensen PS, Sondergaard $\mathrm{HB}$, et al. Effect of natalizumab on circulating CD4+ T-cells in multiple sclerosis. PLoS One. (2012) 7:e47578. doi: 10.1371/journal.pone.0047578

40. Planas R, Jelcic I, Schippling S, Martin R, Sospedra M. Natalizumab treatment perturbs memory- and marginal zone-like B-cell homing in secondary lymphoid organs in multiple sclerosis. Eur J Immunol. (2012) 42:790-8. doi: 10.1002/eji.201142108

41. Paroni M, Maltese V, De Simone M, Ranzani V, Larghi P, Fenoglio C, et al. Recognition of viral and self-antigens by TH1 and TH1/TH17 central memory cells in patients with multiple sclerosis reveals distinct roles in immune surveillance and relapses. J Allergy Clin Immunol. (2017) 140:797-808. doi: 10.1016/j.jaci.2016.11.045

42. van Langelaar J, van der Vuurst de Vries RM, Janssen M, Wierenga-Wolf AF, Spilt IM, Siepman TA, et al. Thelper 17.1 cells associate with multiple sclerosis disease activity: perspectives for early intervention. Brain. (2018) 141:1334-49. doi: 10.1093/brain/awy069

43. Oreja-Guevara C, Ramos-Cejudo J, Aroeira LS, Chamorro B, Diez-Tejedor E. TH1/TH2 Cytokine profile in relapsing-remitting multiple sclerosis patients treated with Glatiramer acetate or Natalizumab. BMC Neurol. (2012) 12:95. doi: 10.1186/1471-2377-12-95

44. Villani S, Zanotta N, Ambrogi F, Comar M, Franciotta D, Dolci M, et al. Multiplex array analysis of circulating cytokines and chemokines in natalizumab-treated patients with multiple sclerosis. J Neuroimmunol. (2017) 310:91-6. doi: 10.1016/j.jneuroim.2017.06.012

45. Ramos-Cejudo J, Oreja-Guevara C, Aroeira LS, de Antonio LR, Chamorro B, Diez-Tejedor E. Treatment with natalizumab in relapsing-remitting multiple sclerosis patients induces changes in inflammatory mechanism. J Clin Immunol. (2011) 31:623-31. doi: 10.1007/s10875-011-9522-x

46. Kimura K, Nakamura M, Sato W, Okamoto T, Araki M, Lin Y, et al. Disrupted balance of $\mathrm{T}$ cells under natalizumab treatment in multiple sclerosis. Neurol Neuroimmunol Neuroinflamm. (2016) 3:e210. doi: 10.1212/ NXI.0000000000000210
47. Stenner MP, Waschbisch A, Buck D, Doerck S, Einsele H, Toyka KV, et al. Effects of natalizumab treatment on Foxp3+ T regulatory cells. PLoS One. (2008) 3:e3319. doi: 10.1371/journal.pone.0003319

48. Traub JW, Pellkofer HL, Grondey K, Seeger I, Rowold C, Bruck W, et al. Natalizumab promotes activation and pro-inflammatory differentiation of peripheral B cells in multiple sclerosis patients. J Neuroinflammation. (2019) 16:228. doi: 10.1186/s12974-019-1593-2

49. Fox RJ, Cree BA, De Seze J, Gold R, Hartung HP, Jeffery D, et al. MS disease activity in RESTORE: a randomized 24-week natalizumab treatment interruption study. Neurology. (2014) 82:1491-8. doi: 10.1212/ WNL.0000000000000355

50. Gonzalez-Suarez I, Rodriguez de Antonio L, Orviz A, Moreno-Garcia S, ValleArcos MD, Matias-Guiu JA, et al. Catastrophic outcome of patients with a rebound after Natalizumab treatment discontinuation. Brain Behav. (2017) 7:e00671. doi: 10.1002/brb3.671

51. Yousry TA, Major EO, Ryschkewitsch C, Fahle G, Fischer S, Hou J, et al. Evaluation of patients treated with natalizumab for progressive multifocal leukoencephalopathy. N Engl J Med. (2006) 354:924-33. doi: 10.1056/ NEJMoa054693

52. Berger JR, Fox RJ. Reassessing the risk of natalizumab-associated PML. $J$ Neurovirol. (2016) 22:533-5. doi: 10.1007/s13365-016-0427-6

53. Carson KR, Focosi D, Major EO, Petrini M, Richey EA, West DP, et al. Monoclonal antibody-associated progressive multifocal leucoencephalopathy in patients treated with rituximab, natalizumab, and efalizumab: a review from the research on adverse drug events and reports (RADAR) Project. Lancet Oncol. (2009) 10:816-24. doi: 10.1016/S1470-2045(09)70161-5

54. Pietropaolo V, Prezioso C, Bagnato F, Antonelli G. John Cunningham virus: an overview on biology and disease of the etiological agent of the progressive multifocal leukoencephalopathy. New Microbiol. (2018) 41: 179-86.

55. Bonig H, Wundes A, Chang KH, Lucas S, Papayannopoulou T. Increased numbers of circulating hematopoietic stem/progenitor cells are chronically maintained in patients treated with the CD49d blocking antibody natalizumab. Blood. (2008) 111:3439-41. doi: 10.1182/blood-2007-09-112052

56. Jing D, Oelschlaegel U, Ordemann R, Holig K, Ehninger G, Reichmann H, et al. CD49d blockade by natalizumab in patients with multiple sclerosis affects steady-state hematopoiesis and mobilizes progenitors with a distinct phenotype and function. Bone Marrow Transplant. (2010) 45:1489-96. doi: 10.1038/bmt.2009.381

57. Warnke C, Smolianov V, Dehmel T, Andree M, Hengel H, Zohren F, et al. $\mathrm{CD} 34+$ progenitor cells mobilized by natalizumab are not a relevant reservoir for JC virus. Mult Scler. (2011) 17:151-6. doi: 10.1177/1352458510385834

58. Zohren F, Toutzaris D, Klarner V, Hartung HP, Kieseier B, Haas R. The monoclonal anti-VLA-4 antibody natalizumab mobilizes CD34+ hematopoietic progenitor cells in humans. Blood. (2008) 111:3893-5. doi: 10.1182/blood-2007-10-120329

59. Marshall LJ, Ferenczy MW, Daley EL, Jensen PN, Ryschkewitsch CF, Major EO. Lymphocyte gene expression and JC virus noncoding control region sequences are linked with the risk of progressive multifocal leukoencephalopathy. J Virol. (2014) 88:5177-83. doi: 10.1128/JVI.03221-13

60. Chalkias S, Dang X, Bord E, Stein MC, Kinkel RP, Sloane JA, et al. JC virus reactivation during prolonged natalizumab monotherapy for multiple sclerosis. Ann Neurol. (2014) 75:925-34. doi: 10.1002/ana.24148

61. Chen Y, Bord E, Tompkins T, Miller J, Tan CS, Kinkel RP, et al. Asymptomatic reactivation of JC virus in patients treated with natalizumab. $N$ Engl J Med. (2009) 361:1067-74. doi: 10.1056/NEJMoa0904267

62. Frohman EM, Monaco MC, Remington G, Ryschkewitsch C, Jensen PN, Johnson K, et al. JC virus in CD34+ and CD19+ cells in patients with multiple sclerosis treated with natalizumab. JAMA Neurol. (2014) 71:596-602. doi: 10.1001/jamaneurol.2014.63

63. Rudick RA, O'Connor PW, Polman CH, Goodman AD, Ray SS, Griffith NM, et al. Assessment of JC virus DNA in blood and urine from natalizumabtreated patients. Ann Neurol. (2010) 68:304-10. doi: 10.1002/ana.22107

64. Chapagain ML, Nerurkar VR. Human polyomavirus JC. (JCV). infection of human B lymphocytes: a possible mechanism for JCV transmigration across the blood-brain barrier. J Infect Dis. (2010) 202:184-91. doi: 10.1086/653823 
65. Perez-Liz G, Del Valle L, Gentilella A, Croul S, Khalili K. Detection of JC virus DNA fragments but not proteins in normal brain tissue. Ann Neurol. (2008) 64:379-87. doi: 10.1002/ana.21443

66. Meira M, Sievers C, Hoffmann F, Haghikia A, Rasenack M, Decard BF, et al. Natalizumab-induced POU2AF1/Spi-B upregulation: a possible route for PML development. Neurol Neuroimmunol Neuroinflamm. (2016) 3:e223. doi: 10. 1212/NXI.0000000000000223

67. Marzocchetti A, Wuthrich C, Tan CS, Tompkins T, Bernal-Cano F, Bhargava $\mathrm{P}$, et al. Rearrangement of the JC virus regulatory region sequence in the bone marrow of a patient with rheumatoid arthritis and progressive multifocal leukoencephalopathy. J Neurovirol. (2008) 14:455-8. doi: 10.1080/ 13550280802356837

68. Wollebo HS, White MK, Gordon J, Berger JR, Khalili K. Persistence and pathogenesis of the neurotropic polyomavirus JC. Ann Neurol. (2015) 77:56070. doi: 10.1002/ana.24371

69. Suzuki T, Yamanouchi S, Sunden Y, Orba Y, Kimura T, Sawa H. Natalizumab has no direct biological effect on JC virus infectivity in permissive human neural cell lines. J Med Virol. (2010) 82:1229-35. doi: 10.1002/jmv.21805

70. Defer G, Mariotte D, Derache N, Toutirais O, Legros H, Cauquelin B, et al. CD49d expression as a promising biomarker to monitor natalizumab efficacy. J Neurol Sci. (2012) 314:138-42. doi: 10.1016/j.jns.2011.10.005

71. Sehr T, Proschmann U, Thomas K, Marggraf M, Straube E, Reichmann H, et al. New insights into the pharmacokinetics and pharmacodynamics of natalizumab treatment for patients with multiple sclerosis, obtained from clinical and in vitro studies. J Neuroinflamm. (2016) 13:164. doi: 10.1186/ s12974-016-0635-2

72. Labrijn AF, Buijsse AO, van den Bremer ET, Verwilligen AY, Bleeker WK, Thorpe SJ, et al. Therapeutic IgG4 antibodies engage in Fab-arm exchange with endogenous human IgG4 in vivo. Nat Biotechnol. (2009) 27:767-71. doi: $10.1038 /$ nbt.1553

73. Rispens T, Leeuwen A, Vennegoor A, Killestein J, Aalberse RC, Wolbink GJ, et al. Measurement of serum levels of natalizumab, an immunoglobulin G4 therapeutic monoclonal antibody. Anal Biochem. (2011) 411:271-6. doi: 10.1016/j.ab.2011.01.001

74. Harrer A, Pilz G, Wipfler P, Oppermann K, Sellner J, Hitzl W, et al. High interindividual variability in the $\mathrm{CD} 4 / \mathrm{CD} 8 \mathrm{~T}$ cell ratio and natalizumab concentration levels in the cerebrospinal fluid of patients with multiple sclerosis. Clin Exp Immunol. (2015) 180:383-92. doi: 10.1111/cei.12590

75. Vennegoor A, Rispens T, Strijbis EM, Seewann A, Uitdehaag BM, Balk LJ, et al. Clinical relevance of serum natalizumab concentration and anti-natalizumab antibodies in multiple sclerosis. Mult Scler. (2013) 19:593-600. doi: 10.1177/ 1352458512460604

76. Tanaka M. Therapeutic drug monitoring of natalizumab. Mult Scler. (2019) 25:1689-90. doi: 10.1177/1352458518813657

77. van Kempen ZLE, Leurs CE, de Vries A, Vennegoor A, Rispens T, Wattjes $\mathrm{MP}$, et al. John Cunningham virus conversion in relation to natalizumab concentration in multiple sclerosis patients. Eur J Neurol. (2017) 24:1196-9. doi: $10.1111 /$ ene. 13355

78. van Kempen ZL, Leurs CE, Witte BI, de Vries A, Wattjes MP, Rispens T, et al. The majority of natalizumab-treated MS patients have high natalizumab concentrations at time of re-dosing. Mult Scler. (2018) 24:805-10. doi: 10. 1177/1352458517708464

79. Harrer A, Pilz G, Einhaeupl M, Oppermann K, Hitzl W, Wipfler P, et al. Lymphocyte subsets show different response patterns to in vivo bound natalizumab-a flow cytometric study on patients with multiple sclerosis. PLoS One. (2012) 7:e31784. doi: 10.1371/journal.pone.0031784

80. Wipfler P, Harrer A, Pilz G, Oppermann K, Afazel S, Haschke-Becher E, et al. Natalizumab saturation: biomarker for individual treatment holiday after natalizumab withdrawal? Acta Neurol Scand. (2014) 129:e12-5. doi: 10.1111/ ane. 12182

81. Cobo-Calvo A, Figueras A, Bau L, Matas E, Mane Martinez MA, Leon I, et al. Leukocyte adhesion molecule dynamics after Natalizumab withdrawal in Multiple Sclerosis. Clin Immunol. (2016) 171:18-24. doi: 10.1016/j.clim.2016. 08.003

82. Khatri BO, Man S, Giovannoni G, Koo AP, Lee JC, Tucky B, et al. Effect of plasma exchange in accelerating natalizumab clearance and restoring leukocyte function. Neurology. (2009) 72:402-9. doi: 10.1212/01.wnl. $0000341766.59028 .9 d$

83. Scarpazza C, Prosperini L, De Rossi N, Moiola L, Sormani MP, Gerevini S, et al. To do or not to do? plasma exchange and timing of steroid administration in progressive multifocal leukoencephalopathy. Ann Neurol. (2017) 82:697-705. doi: 10.1002/ana.25070

84. Harrer A, Wipfler P, Einhaeupl M, Pilz G, Oppermann K, Hitzl W, et al. Natalizumab therapy decreases surface expression of both VLA-heterodimer subunits on peripheral blood mononuclear cells. J Neuroimmunol. (2011) 234:148-54. doi: 10.1016/j.jneuroim.2011.03.001

85. Punet-Ortiz J, Hervas-Garcia JV, Teniente-Serra A, Cano-Orgaz A, Mansilla MJ, Quirant-Sanchez B, et al. Monitoring CD49d receptor occupancy: a method to optimize and personalize natalizumab therapy in multiple sclerosis patients. Cytometry B Clin Cytom. (2018) 94:327-33. doi: 10.1002/cyto.b. 21527

86. Jensen PE, Koch-Henriksen N, Sellebjerg F, Sorensen PS. Prediction of antibody persistency from antibody titres to natalizumab. Mult Scler. (2012) 18:1493-9. doi: 10.1177/1352458512441688

87. Lundkvist M, Engdahl E, Holmen C, Moverare R, Olsson T, Hillert J, et al. Characterization of anti-natalizumab antibodies in multiple sclerosis patients. Mult Scler. (2013) 19:757-64. doi: 10.1177/13524585124 62920

88. Signoriello E, Lanzillo R, Brescia Morra V, Di Iorio G, Fratta M, Carotenuto A, et al. Lymphocytosis as a response biomarker of natalizumab therapeutic efficacy in multiple sclerosis. Mult Scler. (2016) 22:921-5. doi: 10.1177/ 1352458515604381

89. Cassotta A, Mikol V, Bertrand T, Pouzieux S, Parc J. Le, Ferrari P, et al. A single $\mathrm{T}$ cell epitope drives the neutralizing anti-drug antibody response to natalizumab in multiple sclerosis patients. Nat Med. (2019) 25:1402-7. doi: 10.1038/s41591-019-0568-2

90. De Groot AS, Goldberg M, Moise L, Martin W. Evolutionary deimmunization: an ancillary mechanism for self-tolerance? Cell Immunol. (2006) 244:148-53. doi: 10.1016/j.cellimm.2007.02.006

91. Campbell N, Cohen J, Wiendl H, Foley J, Butzkueven H, Zhovtis Ryerson L, et al. Evaluating the Efficacy and Safety of 6-Week Extended Interval Dosing of Natalizumab via a Prospective, Controlled, Randomized, Open-label, Raterblinded Phase $3 b$ Study. (NOVA). Philadelphia, PA: American Academy of Neurology (2019).

Conflict of Interest: The authors declare that the research was conducted in the absence of any commercial or financial relationships that could be construed as a potential conflict of interest.

Copyright (C) 2020 Khoy, Mariotte, Defer, Petit, Toutirais and Le Mauff. This is an open-access article distributed under the terms of the Creative Commons Attribution License (CC BY). The use, distribution or reproduction in other forums is permitted, provided the original author(s) and the copyright owner(s) are credited and that the original publication in this journal is cited, in accordance with accepted academic practice. No use, distribution or reproduction is permitted which does not comply with these terms. 